\title{
THERHOHYDRAULIC MODELING AND SIMULATION OF BREEDER REACTORS
}

\author{
A. K. Agrawal, M. Khatib-Rahbar \\ Brookhaven National Laboratory \\ Upton, New York 11973 USA \\ R. T. Curtis \\ U.S. Nuclear Regulatory Commission \\ Washington, J.C. 20555 USA \\ D. L. Hetrick, P. V. Girijoshankar \\ The University of Arizona \\ Tucson, Arizona 85721
}

BIIL-HUEEG--31104

DES2 013865

\section{L:TRODUCTYON}

An i=portane phase in the design, operation and isery analysis of liquid-ceral-cooled fasc braeder zaccors (LykBRs) iavolves tide prediction or plane asponse ro various rransients. Loss of power to a up, Eurbine trip, or the uncontrolled fithdrawal of a zactcr concrol rod bank are exanples of ancicipaced ridencs. i complete loss of forced cooling or a ajor =upture in the prinaty piping systen with reactor stan are teraed accidental transients.

This paper deals with the modeling and sinulation ¿syscen-ride transients in LyEBRs. "unprotected" yents (i.e., the presumption of failure of the plant rocection systen) leading to core-gelc are not onsidered in this paper. The existing computational ipabilizies in the area of protected transtents in tive .S. are noced. Various pinsical and numerical ?praxications that are jade in these codes are iscussed. Finally, che fucure direction la the area zodel verificalion and izprorements is discussed.

\section{SIMLATIOM A:D PUEICAL YODELI:T}

\section{.1 Sinulacion iporcacnes}

Uyanic sinulation oi complex piysical systens, sei as, nuclear power planes, iubmarines, and trecarics requires idenciticacion of ieporcanc pinysical rocesses and theis achegatical fodeling through riservacion anc canticucive principles. In general, :e solution of these consermation and constiturive ivations rields the desired acale of the s/3tem under :udy. Regardless of the modeling derails, che systen 1. je simuiaced on an analoz, ifzical, or nybrid נapucer $\{1\}$.

There are a nurber or well-detin'd ed rancages and ssadrancages of boch analog and digical conpuiers 121 . : haps the sey jistinction jetween inalug and dizical :mpucers liss la the acuracy ofitered by chem. in alog macinines, cin aceuracy is li=ijed by tie qualizy Z compurer cumponencs ind is rerely jerzer tran j.i:

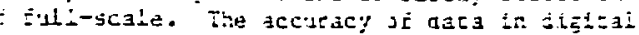

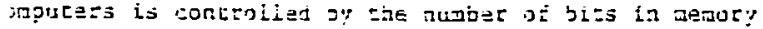

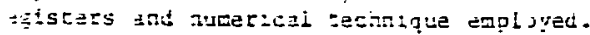

†yjedd sonputer secratques, is the name implies,

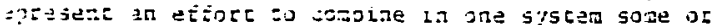

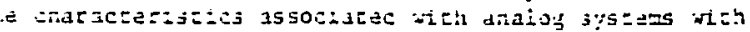

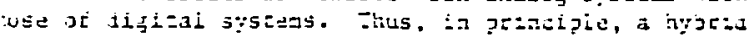

couputer can be utilized as purely anclog or pureiy digical. In accual usage, however, hyoridizacion involves the accual incerconnecting of analog and digital portions witing the system.

Analog coaputers are particularly useful in solving initial value problens in one independent variable. Partial difserential equarions involving two or more Independent variables can be solved by peraitring no more than one variable to vary in continuous form; the remaining variables will then have to be discrecfzed by the application of infle difference approximations.

Digital corputers are capable only of solving algebratc expresstons. Therefore, all independenc variables aust be discretizad. There are a nunjer of numertcal teciniques that have been developed for, and particularly well suiced to digiral conpurers. It should, however, be added chat the digital techriaces are by far the mose popular ones in use.

\subsection{LuFeR Systed Sioulacion Cacabilicies}

The privary aias or decailed syscem siantacion codes are applicucions to sesign, craining and saræa analysis. Table I sumarizes siznizicant piosical processes and the desired nuarerical eficiency for a nubber of represencarife czansiencs ia fifizas. It is, therefore, eyidear that a sinulacor or a system code is expected to yield a consicerable nuaber or che $=$ coiydralic paramecess with engineering accuracy arj reasonable conputational efitetency. The achiewad accuracy is, in pare, deperdenc on the tealisin ot physical and methemacical trodels and thete respectin solutions.

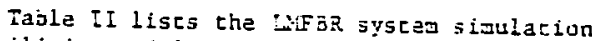
capabilicies and limitacions in the tnited jeates [3].

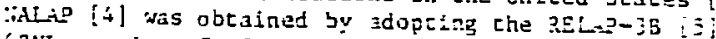
( 3 ill versian of RELAP-3) conputer code ihrough substitution of sodiun properzies inscead of those of wacer. IIrhough this code is capable of providing $a$

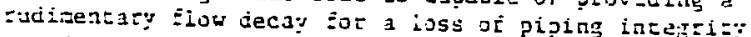
sccident in the primary systed, nany Joceling as weli is jperacing ligicalfors exist.

The Litius [5] code tas deveioned fyr che rast $5:-14$

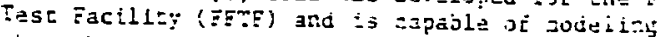

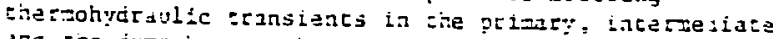

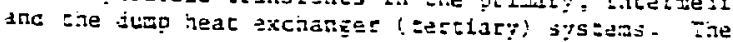


10 (i) code is siailar co IdiNus, and is designed for ecitic appllcation to the Clinch Rlver Breeder actor (CRBR). It rodels the prinary and intermediate at transport systens as well as the steam generatiay scen. LAtius and DENO are specirically designed for rcicular plants and lack anny physical models as marized in Iable II. A version of DENo was veluped at asiL [8] for use in FETF system transient alysis. Yore recently a version of DESIO has been apted to a Pool-type LMFBR [9]. The dynamic gulacton code idicos $\{\mid 0\}$, used for evaluation of erual hydraulic behavior of the ESR-II primary stem, has been linked to DEMO-IV computer code sulting in iATDENO code (11). Application of MATDENo EBR-TI loss of power transients show excellent suemencs Fin key plant variables.

The BRE:ADA [12] coce developed at the University arizona consists of a number of digital simulators epared and mintained as inpue files for the DARE-p fizare system (D1gital inalyzer Replacenent-Port1e). The coce is tntended to orovide convenient and rogical simulations of transients for use in scoping uiies.

The EPSI-CURL $\{13\}$ code developed at CorneII iversity is similar in scope to DEMO code, except for ceer piysical and wachemarical model represertacion, nancing physical and numerical accuracy.

The SSC [ 14$]$ code developed at 3 rookhaven National borztory is a hisiny teneral, state-of-tine-art code c LATSa systen sizuiation studies. It provides thet detailec aodels for processes of interest in the actor core as zell as the heat transport and the ean generating system. Depending upon the transienc be analjzed, the user can choose, through peoriace input dara cards, to eaphas1ze either the -reactor or the balance of plant or botti. This code groviding advanced system transient capability for e U.S. Nuclear Regulatory Comission's LMEBR censing scucies. This code has been in operacion for Ee than four years and it is being used by a . zzer of arfenizations both at home and abroad. It is so beinz raiidaced using the EFTE plant daca as well the fxisting test daca irom various other sonponent ics.

\section{j ?hysical Mocels}

in $\because$ is of the limiced space, it is not possiblo sutail all of the judels that have beer used in EErenc codes. Only bity Features are listed below. $=3$ 507e detailed presencacion, rie reader is

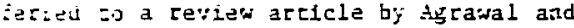
arto-iabiar [1].

The eeactor hear gencration race is invaridoiy presenced jy the poinc-isineties. The encire reactor Ee, in zose detailed system codes, represencs at 15: one or nor $z$ ruel, bianker or control assemolles. = :herai-nodraulies Ehrouthour the plane is yesencef by a suitabiy areraged one-disensional (1n ace) conservacion equations. The aulridimensional Eects say be incorporaled in an approximale way. Eor inpie, parailel teactor channeis in the reactor cose : Ee coupied $\because$ ia sonton pressure hear points in the ie: and upper aiking pletia. These regions themselres - je zode

utzal roluzes; as cone in tie $\mathrm{SSC}$ code $i l+i$.

The pleps that are ised in tive pribary anc

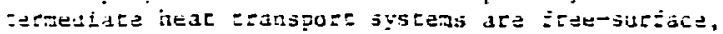
$\because$

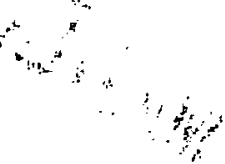

variable speed, centrifugal untes. The lippeller behavior is best characterized by homologous head and corque relations. The transient speed and discharge rate are evaluated fron impellar and coolant dyanic equations. The themal performance of the intermediate heat exchanger, Eor most systen-ride sizulations, can be represented in teras of one equivalent heat transíer tube. Similarly, the steam generatirg system can be wodeled in terus of a single heat transfer tube in eacin of the evaporator and superheater, it they are separate unies, or by a single sube for once-through eype stean generator designs. Due care nust, or course, be given to the different flow regimes on the vater side.

\subsection{Numerical Techniques}

There are two separace problems: one 15 to obcain the sieady-state solution for the entire system wich, then, is used as intelal condition in integrating the time-dependent equarions for all systems and subsystens. The steady-state solutions can best be obcained by solving tice-independent conservation equatons. This method is superior to the one in which the plant is inflalized by numertcally Forcing time-derivacive terns of the time-dependent equations to approach zero. The second part oi the problem is considerably more 1nvolved and interesting since the ent1re systen is comprised of processes which have characteristic time constants varying over a few orders of ragnitude [15]. This results in a rather "stife" set of equations. Grouping of variables that concribute to these smail cime contants and integrating then with saall step size while using large step sizes for the rest of the variables has bees one of the approaches to lintt the compucer time. This particion1ng of vartables has been done in the SSC code on the basts of physical arguments and has been found to be succesful. The same underlying principle is used 1 in the EPRI-CLRL code. The experience to date shows savings in computing clae by a Eactor of up to four. The method of separting the Fast and sluw variables has been studied aachenatically [16] for linear systens and applied to non-linear systems by Girijastnanker et al., $\{17\}$ and has been successiuly cested For a pressurized water reactor system. The utility of this scrieme could be considerably eninanced if ic could be made aucomacic.

\section{FUTURE DIAECTIONS IV L.MFBR SIMTLLIION}

The future erfort in the area of LUFBR simulation may be divided 1nto four caregortes: nodel faprovesents, accident management, numerical zethods, and compucer code verification. In the istst caceyor: modeling inprovements are needed for the hot-spor core temperatures to account for (1) key uncercainties in the fusl-clad gap conductance, (2) inter- and intra-assemily heat rediscribution at low flows, (3) the gixing and stratification of sodiua in large bodies sucin as the plena in the reactor vessel and the inceraediate heat exchange:, and (i) stratilication i. the pipings. A better underscanding of the sodium boillng and posi-boiling efiects at low Elows and Lor heat Elux will also be desirable.

The area of acctienc managegrnt is beginning to $\xi \equiv c$ the tc:encion ic deserves. Yuch ui gne simuiatiun studies ayo jeen tirected sowares finciag the consequences gi design jasis accidents. In vier of recene TII-: experience, sieulation for jernod des jasij zccidents, wita emphasis on enzizeer joceas, should be sonsidezed. 
In the area of compucacion mechods, there is lways a destre for more efficient integracion schemes. here is a yrowng 1nterest In real-time (or raster) inulation. Invartably this would loply maklag some ompronise on the modeling level.

The area of compucar code verfilcation really has do parts: one to ascertaln chat the code is doing wat it was Intended to do, and the second to ascertain hether the code 1 s simulating realistically. The irst part is relatively easier to verify via incersce comparisons and "1solaced" analytical soluctons. he second part is more involved-it can be cone hrough code applications to the whole plant data as ell as phenomemological tests. This phase of code erification is a continuing process and it must be atried our in order to provide coníidence in the anlycical sools.

\section{REFERE:SCES}

Agrawal A. K., and kharib-Ranbar, Y., "Dynanic Simulacion of Wifuk Syscems", Atomic Enerğy Revies 13. $329(1980)$.

- BekEy, G. A., and Earplus, $h . J .$, "Hybrid Computarion, John Wiley ó sons, Inc., Vyei lork (19bó).

- Shacib-Pahbaz, M., ec al., "LuEBR System-iide Transient Analysis: The Scate of the art and U.S. Valication Needs", in Proc. of the Inc. Heeting on HAFBR SaFecy and Relaced Design anc Dperaclonal Aspects, Lyon-Eculiy, Erance (July 19-23, 1982).

- Macia, b., et al., "ialde: an LUFBR syscen Transfent Code", 3rookhaven Jacional Laboracory, RP-1035 (Dec. 1974).

"PELtP33 :Lanual, A reaccor System Iranslent Code", grookinaven National Laboratory, RP-1035 (Dec. $1974)$

- didicon, 5. L., et el., "LANus-Outlize Desczipcion", Hestingiouse idvanced Reactors Divsion, $\equiv ? C-939$.

illiseon, $\ddot{i}$. H., et al., "Lituk Cemonstracion Plane

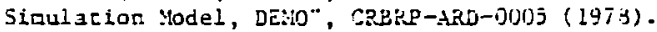

- Perkins, :. ․, Jari, 3. A.. Chan, L. C. Albrigit, D. C. "Analyses of EETE 5 yssen Iransiencs", 3:iL-NUEEC-25560 (Jan. 1979).

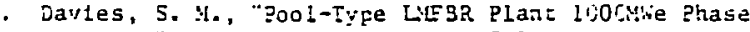

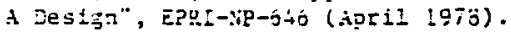

.. :tohe, D., "vircon, A Dynanic Code for Evaluating Ene Theraal-yodraulic 3ehzuior of the EzR-II Pria-

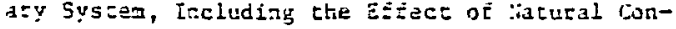
Jectisn", Alit-?.0p-74, p. l.1: (sug. 1973).

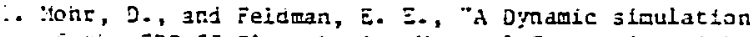
OE Ge EBR-il Planc Juring Iacural Convecelon wirh YHTDE:O Code“, in Decay Heac Removal and Satural

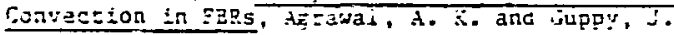
j., Eds., Kenlspnere publtsining co., (!yjl).

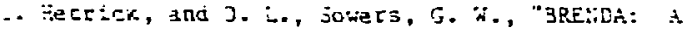

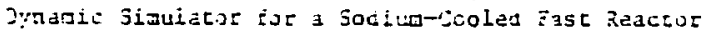
?ower ? Ianc", :(1)

$\therefore$ Shat

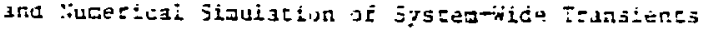

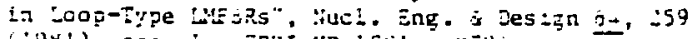

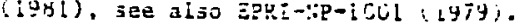

14. Agrawal, d. K., et al., "Ar Advanced The r.gohydraulic Stmulation Code for Transienes in LMFBRS (SSC-L Code), 3NL-VUREG-50773 (Eeb. 1973).

15. Agrawal, A. K., "Numerical Consideraclons in jegR Advanced The rmal Transient Code SSC", Trans. im. Nucl. Soc., 21, 219 (1975).

16. O'Malley, R. E., Jr. and Anderson, L. R., "Siggular Perturbations, Order Reduction, and Decoupling or Larze Scale Systems", 1n Huerical Analysis of Singular Percubation Problems, P. W. hemker and J. J. H. Willer, Eds., dicadenic Press, London, (1979).

17. Girljashankar, P. V., Hecrlck, D. L., Keepin, 'i. N., and Palusinski, 0. A., "i Techniçue for EEEfclent Simulacion of Laró Dymamic systed", Joint Automatic Control Conference, Vol. 1 , HPS-A, (1980). 


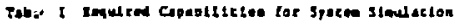

\begin{tabular}{|c|c|c|c|c|}
\hline Tranaleat chase & Exnabie of Evants & 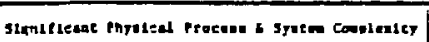 & 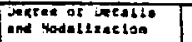 & $\begin{array}{l}\text { isporzance at } \\
\text { Yumeteltetes. }\end{array}$ \\
\hline Eparacson & 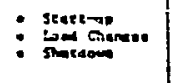 & 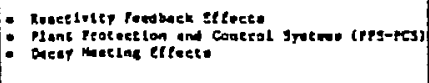 & 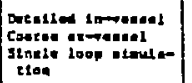 & Andue \\
\hline lacidental & 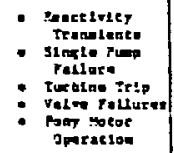 & 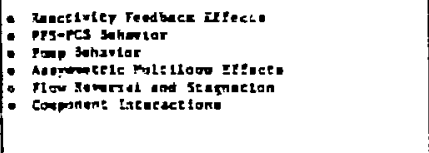 & 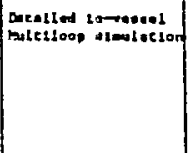 & Rlan \\
\hline Metamist & 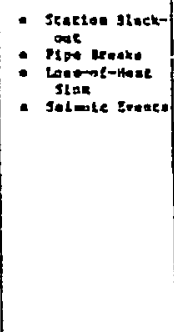 & 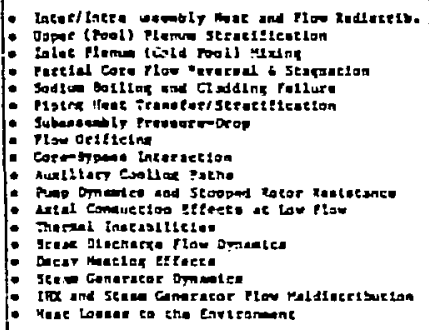 & 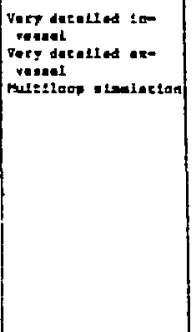 & Vaty 4t gan \\
\hline
\end{tabular}

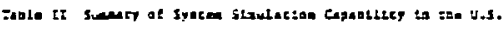

\begin{tabular}{|c|c|c|c|c|c|c|c|c|}
\hline es & 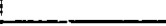 & & 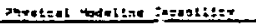 & & Asthenetest ans & تjezurstigned & 4asace: & \\
\hline 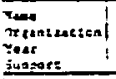 & seats & & Dolfue FactureA & Habcastos & $\begin{array}{l}\text { Seluk:aa } \\
\text { Jechnlquese }\end{array}$ & $\begin{array}{l}\text { gotaus } \\
\text { Seceurat }\end{array}$ & $\begin{array}{l}\text { CCasousane } \\
\text { Gpersale }\end{array}$ & \\
\hline $\begin{array}{l}\text { inith } \\
\text { lyt } \\
\text { igls } \\
\text { inge }\end{array}$ & 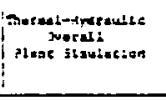 & & 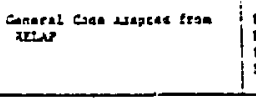 & 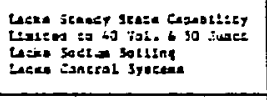 & Sesbles: & - & cose-1600 & \\
\hline 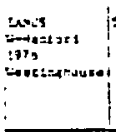 & 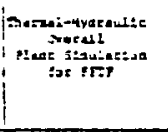 & & 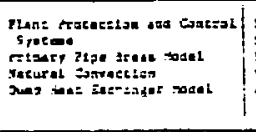 & 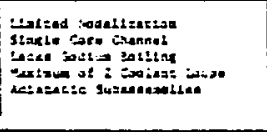 & 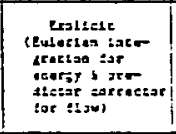 & - & 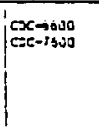 & \\
\hline 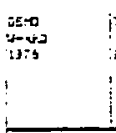 & 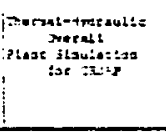 & 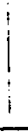 & 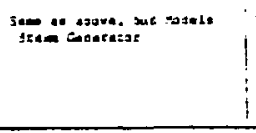 & 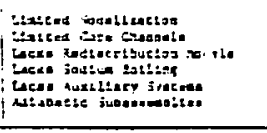 & Enslices & Xsecep seate. & $i=0-\ln 00$ & \\
\hline 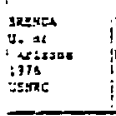 & 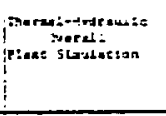 & $i$ & 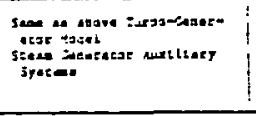 & 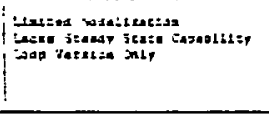 & 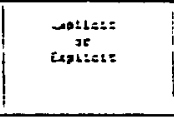 & 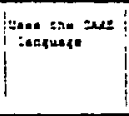 & $\cos _{0 x-i s i 0}$ & \\
\hline 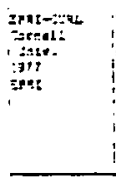 & 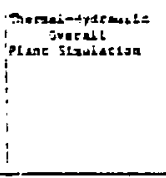 & $\vdots$ & 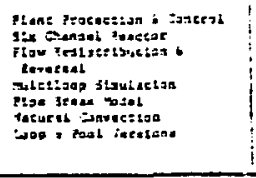 & 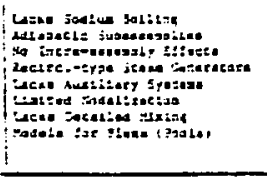 & sests $=12$ & 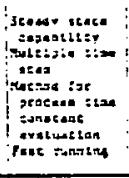 & 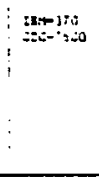 & \\
\hline 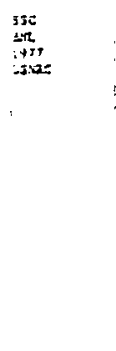 & 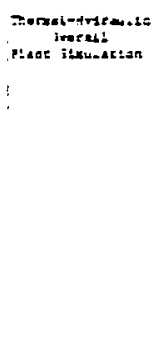 & $i$ & 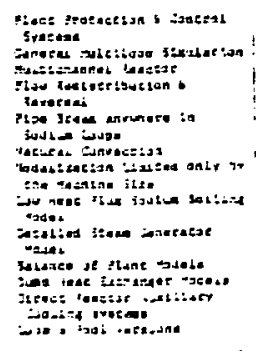 & 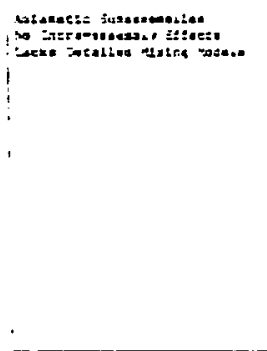 & ima-sadbetr & 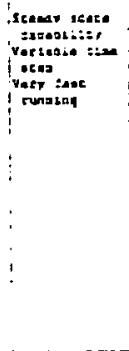 & : & \\
\hline
\end{tabular}

